\title{
Code Switching and Code Mixing in English Language Learning Class
}

\author{
Theresya Adhelya Pharamita \\ University of Bengkulu \\ theresyapharamita@gmail.com
}

\author{
Mei Hardiah \\ University of Bengkulu \\ mhardiah@unib.ac.id
}

\section{Indah Damayanti}

University of Bengkulu

indahd@unib.ac.id

Corresponding email: theresyapharamita@gmail.com

\begin{abstract}
This research concerned with the types of code switching and code mixing used by the teachers, teachers' reasons in using code switching and code mixing, and students' perception of code switching and code mixing used by the teacher in the class. This research was a descriptive qualitative research. The researcher used observation checklist, video recording, interview, and questionnaire as the instruments of this research. The data of this research was analyzed by classifying the types of code switching used theory of Poplack and the types code mixing used theory of Hoffman. The result of this research shows that the English teachers did all the types of code switching in English class. Namely; tag code switching, inter-sentential code switching, and intra-sentential code switching. Meanwhile, the researcher found that the teachers only used two from the three types of code mixing. Namely; intra-sentential code mixing and intra-lexical code mixing. The type that did not appear was involvement in a change of pronunciation. This study revealed that the teachers' reason in using code switching and code mixing are; to help the students in learning English and to make the students more focus in learning process. For the students' perception, most of the students agreed that the use of code switching and code mixing helps them understand the materials in English language learning class.
\end{abstract}

Keywords: code switching, code mixing, English language learning class 


\section{Introduction}

At the moment, there are significant numbers of people who master more than one language. The language which is usually mastered well by people is their mother tongue. According to Muin (2011), people who use two or more languages are called bilingual or multilingual. Bilingual means when people or certain communities use two languages when they are communicating. According to Mokibelo (2015), the bilingual speakers have the aptitude of mastering and use two languages in daily communication. On the other hand, multilingual is the act of using more than two languages by certain individuals or communities. Bilingual or multilingual also happen in Indonesia.

In Indonesia, people usually master their mother tongue as their first language; meanwhile, some people who experience in education must be able to speak Indonesian language as the national language. Briefly, it can be said that many people in Indonesia normally use two languages in their daily life or it can be said that Indonesian people are bilingual speakers.

Due to the existence of bilingual or multilingual phenomenon in Indonesian society, people sometimes produce certain codes. The meaning of code is variety of language or it is the choice of the words in communication. There are two types of codes, namely code mixing and code switching.

Likhitphongsathorn and Sappapan (2013) define code switching as a means of communication involving a speaker alternating between one language and another at the level of sentence. Meanwhile, According to Maazrani (2013), Syafryadin \& Haryani (2020) and Syafryadin, et al. (2020) define code mixing as the mixing of different varieties within a single utterance or even another single word. It is in line with the example that given by Rismawati (2016), “Tampangnya yang sok innocent saat ospek membuatku dan Bima sangat hobi menjahilinya".

In the English language learning class, the use of code switching and code mixing by the teacher may occur in explaining the materials. These are 
caused by several factors, for example students who lack mastering of vocabulary in English and avoid being unclear in explaining the materials. Besides, the students also do not master a lot of English vocabulary if their English teachers explain the materials in totally in English. In this case, the English teachers sometimes use more than one language when they are teaching the materials. The teachers switch and mix English and Indonesian language.

According to the research, there were several studies that are related with this research. Firstly, the study conducted by Asror (2009) entitled “Teachers' Explaining Techniques: Code Switching and Code Mixing in the Classroom". The result shows that: (1) the total number of code switching and code mixing made by the teachers was 148 utterances, (2) the function of 37 utterances or $25 \%$ were to ease communication.

Secondly, the study from Khairunnisa (2016) entitled "Code Mixing Analysis in English Teaching Learning Process at Senior High School 1 Takalar". This research investigated the use of code mixing by the teacher in English teaching learning process at language class the first grade of SMA 1 Takalar. The results revealed that there are three types of code mixing, namely; intra-sentential code mixing, intra-lexical code mixing, and involving a change of pronunciation.

Thirdly, the study from Sihite (2016) entitled "Code Mixing and Code Switching Used by English Lecturers at Jambi University". The outcomes of the study are as follows; first, from six types of code mixing based on the Suwito's theory, there are only 4 types code mixing used by the lecturers, they are insertion of word (29), the insertion of phrase (47), and the insertion of hybrid (16), and the insertion of idiom (3). Meanwhile there are two types of code switching; they are metaphorical code switching (6) and conversational code switching (112).

Then, the study from Ramadhaniarti (2017) with the title "Code Mixing in English Classes of SMP N 14 Kota Bengkulu: Views from the teachers", the researcher found that teachers used inter-sentential code mixing more 
frequently than intra-sentential code mixing. It is also found that all of the teachers used code mixing in pre-activity, while activity and post-activity in their English classes.

Next, the study from Alawiyah (2018) with the title "Code mixing used by English teachers at SMA N 9 Kota Bengkulu". This research revealed the types and function of code switching used by English teachers at SMA N 9 Kota Bengkulu. The findings of this research are; (1) there were three types of code switching based on Poplack (1980), namely; intrasentential, inter-sentential, and tag switching (2) clarification became the highest function of code switching used by English teachers in teaching and learning process, the teachers often switched to Indonesian language as the teacher repeated or paraphrased something that had just said in English.

The last was Zetri (2018) with the title "An analysis of code mixing in a debate activity as part of English club programs at SMAN 2 Bengkulu city". The result showed that there were two types of code mixing applied by the students in debate activities. The type of code mixing appeared were insertion of word code mixing and insertion of phrase code mixing.

Furthermore, the previous studies only focused on the types of code switching and code mixing. Whereas, this study also focuses on the teachers' reasons in using code switching and code mixing. Moreover, this study also focuses about students' perceptions of code switching and code mixing used by the teachers.

Considering the code switching and code mixing phenomenon that often happen in English language learning class, the researcher conducted the research entitled "Code Switching and Code Mixing in English language learning class".

\section{Research Methodology}

This research used a descriptive qualitative method to reveal code switching and code mixing in English class. According to Creswell (2001), qualitative research is concerned in describing that thesearcher is 
interested in processing and understanding the meaning increased through words or pictures. The subjects of this study were two English teachers who teach in first grade at SMA N 5 Kota Bengkulu. The instruments in this research were video recording, observation checklist, interview, and questionnaire. The data were analyzed by using coding, summarizing and classifying.

\section{Results and Discussion Results}

The data of this research have been collected and analyzed in order to get the description about the types of code switching and code mixing used by the English teachers, the teachers' reasons in using code switching and code mixing, and students' perception about code switching and code mixing used by the teachers.

\section{Types of code switching and code mixing used by the English teachers}

In this section, the researcher presented the data findings about the types of code switching and code mixing used by the English teachers in the classroom. In classifying the types of code switching, the researcher employed Poplack's theory. According to Poplack (1980) there are three types of code switching, namely; tag switching, inter-sentential code switching and intrasentential code switching.

This researcher revealed that the English teachers did all the types of code switching in the classroom. The types of code switching that appear in this research were; A tag code switching, Inter-sentential code switching, and Intra-sentential code switching. Furthermore, the examples of code switching that is found in teachers' utterances will be described as follows:

1.) Tag code switching

Tag code switching happens when a bilingual or multilingual speaker inserts short expressions (tag) from different language. Tag code switching includes interjections, fillers, tags, and idiomatic expressions. 
Ya, the use of too and enough.

Please, exchange your paper, ya.

You can say too complicated, ya.

Present perfect, betul?

2.) Inter-sentential code switching

Inter-sentential code switching is described as the switch between sentence boundaries, where one sentence is in one language and other in another.

Undeleagable, it means tidak bisa didelegasikan.

Jangan nyontek, no cheating.

What was my question? Apa pertanyaan saya tadi?

3.) Intra-sentential code switching

Intra-sentential code switching is the shift of words or phrases other language in one sentence. The word class that usually comes in intra-sentential code switching is verb, adjective, and adverb.

Nah ini loose longgar, tight ketat.

Apa efek dari mandi? Segar. Fresh.

Moreover, there are three types of code mixing according to Hoffman (1991). Those types are Intra-sentential, Intra-lexical, and Involvement in a change of pronunciation. From the gained data, the English teachers only used two types of code mixing in their utterances while teaching English. Those types were Intra-sentential code mixing and Intra-lexical code mixing. Meanwhile, the type that did not appear was involvement in a change of pronunciation. Furthermore, the examples of code mixing that is found in teachers' utterances will be described as follows:

1.) Intra-sentential code mixing

This type means that the occurrence of code mixing is within a words or phrases boundary. atau problem artinya it.

Saya mau ngasih latihan yang lebih challenging lagi. 
Jadi, kadang apa yang kita lihat juga perspective, gak real.

2.) Intra-lexical code mixing

This type means that the occurrence of code mixing is in word boundary.

This type can be seen in affixes. In this type, the position of the affixes is either in the initial or in the final position of the words.

Kita harus memahami pertama meaningnya dulu Sekarang kita lihat formnya

\section{Teachers' reasons in using code switching and code mixing in English language learning class}

To obtain data of the English teachers' reasons in using code switching and code mixing in English language learning class, the researcher conducted the interviews with two English teachers in 20th and 22nd January 2020. The researcher found that there were several reasons why the English teachers used code switching and code mixing occurs in the class;

A. eacher 1

Based on the interview with the teacher 1 about the reasons of using code switching and code mixing in the class, the researcher got some reasons why the teacher used code switching and code mixing in his teaching class such as; (1) the teacher uses code switching and code mixing because students' abilities in English are different, (2) the teacher also uses code switching and code mixing as the strategy in teaching English. Therefore, the teacher wants to make his utterances clearer when giving explanation so the students could understand the materials.

B.

Based on the interview with the teacher 2, the researcher got some reasons why the teacher uses code switching and code mixing in class such as; (1) the teacher uses code switching and code mixing because it depends on the materials, (2) the teacher uses code switching and code mixing in order to make the students' focus in learning process, (3) the teacher uses 
code switching and code mixing because students' abilities in English are different.

\section{Students' perceptions of code switching and code mixing used by the English teachers in English language learning class}

The researcher obtained data about students' perceptions of code switching and code mixing used by the English teachers in the class, by adopting the questionnaire from Nursanti (2016). The total numbers of the students for this research were 43 students from six classes. This was done from 14th January to 22nd January 2020.

Table 1. Students' perception of code switching and code mixing used by the English teachers in the classroom

\begin{tabular}{|r|l|l|l|l|l|}
\hline No. & \multicolumn{1}{|c|}{ Statements } & SA & A & DA & SDA \\
\hline 1. & $\begin{array}{l}\text { The use of Indonesian language by } \\
\text { the teacher in English classroom helps } \\
\text { you in learning English. }\end{array}$ & $\mathbf{2 3}$ & 15 & 5 & 0 \\
\hline 2. & $\begin{array}{l}\text { The use of Indonesian language by } \\
\text { the teacher in English classroom } \\
\text { makes you easy to understand the } \\
\text { material given by the teacher. }\end{array}$ & 17 & $\mathbf{2 3}$ & 2 & 1 \\
\hline 3. & $\begin{array}{l}\text { The use of Indonesian language by } \\
\text { the teacher in English classroom } \\
\text { makes you easy to understand new } \\
\text { vocabularies in English. }\end{array}$ & $\mathbf{2 2}$ & 16 & 4 & 1 \\
\hline 4. & $\begin{array}{l}\text { The use of Indonesian language by } \\
\text { the teacher in English classroom helps } \\
\text { you to be fluent and accurate on } \\
\text { your English speaking skill. }\end{array}$ & 12 & $\mathbf{1 6}$ & 13 & 2 \\
\hline 5. & $\begin{array}{l}\text { The use of Indonesian language by } \\
\text { the teacher in English classroom }\end{array}$ & 6 & $\mathbf{1 8}$ & 17 & 2 \\
\hline
\end{tabular}




\begin{tabular}{|r|l|l|l|l|l|}
\hline & makes you easy in English writing skill. & & & & \\
\hline 6. & $\begin{array}{l}\text { The use of Indonesian language by } \\
\text { the teacher in English classroom } \\
\text { makes you understand toward the } \\
\text { meaning of every sentence which is } \\
\text { explained by the teacher. }\end{array}$ & 18 & $\mathbf{2 2}$ & 2 & 1 \\
\hline 7. & $\begin{array}{l}\text { The use of Indonesian language by } \\
\text { the teacher in English classroom } \\
\text { makes you understand something } \\
\text { faster and it helps your teacher in } \\
\text { managing the time in explaining } \\
\text { thing. }\end{array}$ & 12 & $\mathbf{2 4}$ & 6 & 1 \\
\hline 8. & $\begin{array}{l}\text { The use of Indonesian language by } \\
\text { the teacher in English classroom } \\
\text { makes you confused to learn English. }\end{array}$ & 2 & 4 & $\mathbf{2 3}$ & 14 \\
\hline
\end{tabular}

Notes:

SA $=$ Strongly Agree

$\mathrm{A}=$ Agree

DA $=$ Disagree

$\mathrm{SDA}=$ Strongly Disagree

From the first statement, it can be seen that there were 23 students who are strongly agreed with the use of Indonesian language by the English teachers in English classroom. Next, there were 15 students who are agreed if the teacher uses Indonesian language in the class. Meanwhile, there were 5 students who disagreed with this statement. Then, there were not a single student who strongly disagreed with the first statement. 
The second statement showed that there were 23 students who agreed if the use of Indonesian language by the English teachers in English class makes them easy to understand the material given by the teacher. Next, there were 17 students who strongly agreed with this statement. Meanwhile, there were 2 students who disagreed if the use of Indonesian language in the class makes them easy to understand the material given by the teacher. On the other hand, there was only 1 student who disagreed with this statement.

The third statement showed there were 22 students who strongly agreed if the use of Indonesian language in English language learning class by the teacher in makes them easy to understand new vocabularies in English. Besides, there were 16 students who agreed with the third statement. Next, there were 4 students who disagreed if the use of Indonesian language in English class makes them easy to understand new vocabularies in English. Meanwhile, same as the second statement, there was only 1 student who disagreed if their teacher use Indonesian language in English language learning class makes them easy to understand new vocabularies in English.

Next, based on the fourth statement there were 16 students who agreed if the use of Indonesian language by the teacher in English language learning class helps them to be fluent and accurate on their English speaking skill. Moreover, there were 12 students shared their ideas strongly agreed with this statement. On the other hand, there were 13 students who disagreed with this statement and 2 students who disagreed if their English teacher use Indonesian language in English language learning class helps them to be fluent and accurate on their English speaking skill.

Then, from the fifth statement showed that there 18 were students agreed if the use of Indonesian language by the teacher in English language learning class makes them easy in English writing skill. Furthermore, there were 6 students who strongly agreed with this statement. Meanwhile, there were 17 students who disagreed if the use of Indonesian language by the teacher in 
English language learning class makes them easy in English writing skill. Besides, there were 2 students who strongly disagreed with this statement.

Next, based on the sixth statement there were 22 students who agreed if the use of Indonesian language by the teacher in English language learning class makes them understand toward the meaning of every sentence which is explained by the teacher. Furthermore, there were 18 students who strongly agreed with this statement. On the other hand, there were 2 students who disagreed and there was only 1 student who strongly disagreed if the use of Indonesian language by the teacher in English language learning class makes them understand toward the meaning of every sentence which is explained by the teacher.

Based on the seventh statement that is about the use of Indonesian language by the teacher in English language learning class makes the students understand something faster and it helps their teacher in managing the time in explaining materials. There were 24 students who agreed with this statement. Furthermore, there were 12 students who strongly disagreed with this statement. Meanwhile, there were 6 students who share their ideas disagreed and there was only 1 student who disagreed if the use Indonesian language by the teacher in English language learning class makes the students understand the material faster.

The last statement showed that there were 2 students who strongly agreed if the use of Indonesian language by the teacher in English class makes them confused to learn English. Next, there were 4 students who agreed with this statement. Meanwhile, there were 23 students who disagreed if the use of Indonesian language by the teacher in English language learning class makes them confused to learn English. Furthermore, there were 14 students who strongly disagreed with this statement.

\section{Discussion}

As mentioned in result, the researcher found that the teachers use code switching and code mixing in learning process. This finding is in line with 
the study from Asror (2009). The result of his study showed that the teachers use code switching and code mixing when the teachers explain the materials. Furthermore, the researcher found that the teachers did all the types of code switching in English class. Those types are; tag switching, inter-sentential code switching, and intra-sentential code switching. Moreover, tag code switching includes interjections, fillers, tags, and idiomatic expressions. Based on this research, the English teachers only used tags when they were explaining the materials in learning process.

Meanwhile, the researcher found that there were only two types from the three types of code mixing used by the teachers in English class. Those types were; intra-sentential code mixing and intra-lexical code mixing. Meanwhile, the type that did not appear was involvement in a change of pronunciation. Due to absence, the researcher assumed that the English teachers have mastered how to pronounce English words correctly. This result finding is different to the study from Khairunnisa (2016). Since, in her study, she found that the teachers used all of the types of code mixing. Those types were; intra-sentential code mixing, intra-lexical code mixing, and involvement in a change of pronunciation.

Furthermore, this research revealed that the teachers use code switching and code mixing because it would help the students to understand the materials. It might be happened because nowadays the students' admission system is through zonation system. It can be implied that the English teachers especially at SMA N 5 Kota Bengkulu may occasionally use code switching and code mixing, in this case the teachers use Indonesian language and English to make students understand the material easily. This is in line with the finding of Sofyan (2006). His research showed that in this case, students and teachers are required to comprehend English. Nevertheless, it does not cover the possibility that the teachers will do the code switching when explain the materials in English class.

Based on the interviews with the English teachers in this research, the researcher concluded that the use of code switching and code mixing by 
the English teachers helps the students to enjoy their learning English. Moreover, based on the data interview from teacher 2 , she stated that she uses code switching and code mixing in order to make the students more focus in learning process. This result finding is in agreement with the study from Ibralinanto et al. (2018). They stated that the teachers' code switching has improved the students' motivation to learn.

Moreover, the data from the questionnaire also showed that the students agreed if the use of Indonesian language by the teacher in English classroom makes them easy and understand in learning English. It can be seen from the second, third, sixth, and seventh statements there was only one student who share their ideas strongly disagreed. It can be implied that almost a half of the students agreed if the use of Indonesian language by the teacher makes them easy and understand in learning English. This is also supported by statement from teacher 1. From his statement, the teacher uses code switching and code mixing as the strategy in teaching English. This finding is in line with the study from Weng and Shi (2012) since they stated that the use of code switching by the teacher can be seen as a kind of teaching strategy to help students.

Briefly, the researcher concludes that some facts related to this research. First, based on the result finding, the teachers did all the types of code switching in the class. Namely; tag code switching, inter-sentential code switching, and intra-sentential code switching. Meanwhile, the researcher found that there were only two types from the three types of code mixing used by the teachers in the class. Those types were; intra-sentential code mixing and intra-lexical code mixing. Second, based on the interviews with two English teachers, the researcher concludes that the use of code switching and code mixing by the teachers helps the students to understand the materials easily. Similarly, the teacher use code switching and code mixing as the strategy in teaching English. The last, the data from the questionnaire showed that the students agreed if the use of Indonesian language by the teacher in English class makes them easy and understand in 
learning English. Also, the students agreed if the use of Indonesian language by the teacher in English class helps them in learning English easily.

\section{Conclusion and suggestions}

\section{Conclusion}

After doing the research, it can be concluded that; firstly, based on the obtained data, the English teachers did all the types of code switching in the classroom. The types of code switching that appear in this research were; tag code switching, Inter-sentential code switching, and Intra-sentential code switching. Meanwhile, the English teachers only used two types of code mixing in their utterances while teaching English. Those types were Intra-sentential code mixing and Intra-lexical code mixing. Instead, the type that did not appear is involvement in a change of pronunciation.

Secondly, the researcher concluded that there are several reasons why code switching and code mixing occurs in teachers' utterances, they were; (1) the teacher uses code switching and code mixing because students' abilities in English are different, (2) the teacher also uses code switching and code mixing as the strategy in teaching English, (3) the teacher uses code switching and code mixing because it depends on the materials, (4) the teacher uses code switching and code mixing in order to make the students' focus in learning process.

Lastly, based on the obtained data related with students' perception on code switching and code mixing used by the English teachers in the class, it can be concluded that the most of the students deliver their ideas agreed if the use of Indonesian language by the teacher in English classroom helps them in learning English easily.

\section{Suggestions}

For the English teachers, the use of code switching and code mixing by the English teachers in the class can be used as a strategy in teaching 
English. Moreover, the use of code switching and code mixing by the English teachers can help the students easy to understand the materials.

For future researcher, it is expected that the result of this study can be as reference to conduct a further research that is related with using code switching and code mixing in English teaching process.

\section{References}

Alawiyah, T. (2018). Code switching used by English teachers at SMA N 9 Kota Bengkulu. University of Bengkulu. Unpublished Thesis.

Asror, M. (2009). Teachers' explaining techniques: Code Switching and code mixing in the classroom. Semarang State University. Published Thesis.

Creswell, John W. (2001). Research design: Qualitative, Quantitative, and Method Approached. California. Sage Publication, Inc.

Hoffman, C. (1991). An introduction to bilingualism. New York: Longman.

Ibralinanto, Y., Kasmaini., \& Imranuddin. (2018). Multilingual Learners' Attitude towards Code Switching in English Classroom. Unpublished Thesis.

Khairunnisa. (2016). Code mixing Analysis in English Teaching Learning Process at Senior High School 1 Takalar. Alauddin State Islamic University of Makassar: Published Thesis.

Likhitphongsathorn, T. \& Sappapan, P. (2013). A study of English code mixing and code mixing in Thai pop songs. Thailand: Thammarat University, p.494-505.

Maazrani, N. (2013). Aspect of language variation in Arabic political speech-making. Richmond, Surrey: Curzon Press, p. 249-257.

Mokibelo, E. (2015). Multilingualism and multiculturalism in the education system and society of Botswana. US-China Education Review B, 5(8), 488-502.

Muin, A. (2011). Code switching as a communication and teaching Strategy. Jurnal Adabiyah, 11(2), 265-266.

Nursanti, Y. (2016). Students' Perception of Teacher's Bilingual Language Use in an English Classroom. UPI Journal of English and Education, 4(1),159-176. 
Poplack, S. (1980). Sometimes I'll Start a Sentence in Spanish y termino en Espanol: Toward a typology of code switching. Linguistics, 18 (7), 581-

618.

Ramadhaniarti, T. (2017). Code Mixing in English Classes of SMP N 14 Kota Bengkulu: Views from the Teacher. Journal of Applied Linguistics and Literature (JOALL), 2(1), 6-8.

Rismawati, R. D. (2016). English and Indonesian Code Mixing in Novel "Marriage of Convenience”. Muhammadiyah University of Surakarta. Published Thesis.

Sihite, D.R. (2016). Code Mixing and Code Switching Used by English Lecturers at Jambi University. Jambi University. Published Thesis.

Sofyan, D. (2006). Pemicu Alih Kode Inggris-Bahasa Indonesia: Kasus Percakapan Diskusi Kelas Siswa dan Guru Sekolah Nasional Plus Delima, Jakarta. Universitas Indonesia.

Syafryadin, S., \& Haryani, H. (2020). An analysis of English code mixing used in Indonesian magazine. Journal of Languages and Language Teaching, 8(4), 381-390.

Syafryadin, S., Rahmawati, I. N., \& Febriani, R. B. (2020). An analysis of code mixing used in opinion rubric of kompas newspaper. English Education: Jurnal Tadris Bahasa Inggris, 13(2), 173-193.

Weng \& Shi,P. (2012). Code Switching as A Strategy Use in an EFL Classroom in Taiwan. Taiwan: Tamkang University.

Zetri, D.E. (2018). An analysis of code mixing in a debate activity as part of English club programs at SMAN 2 Bengkulu city. Journal of English Education and Teaching (JEET), 2(2), 4-7. 